\title{
The effect of diet, temperature and intermittent low oxygen on the metabolism of rainbow trout
}

\author{
Kevin T. Stiller ${ }^{1,2,3 *}$, Klaus H. Vanselow ${ }^{1}$, Damian Moran $^{4}$, Guido Riesen ${ }^{5}$, Wolfgang Koppe ${ }^{5}$, \\ Carsten Dietz ${ }^{6}$ and Carsten Schulz ${ }^{2,3}$ \\ ${ }^{1}$ Forschungs- und Technologiezentrum Westküste, Christian-Albrechts-Universität zu Kiel, Hafentörn 1, 25761 Büsum, \\ Germany \\ ${ }^{2}$ Gesellschaft für Marine Aquakultur, Hafentörn 3, 25761 Büsum, Germany \\ ${ }^{3}$ Institute of Animal Breeding and Husbandry, Christian-Albrechts-Universität zu Kiel, Olshausenstraße 40, 24098 Kiel, \\ Germany \\ ${ }^{4}$ Seafood Technologies Group, Plant and Food Research, Nelson 7010, New Zealand \\ ${ }^{5}$ Skretting Aquaculture Research Centre, Sjøhagen 15, 4016 Stavanger, Norway \\ ${ }^{6}$ Georg-August-Universität, Wilhelmsplatz 1, 37073 Göttingen, Germany \\ (Submitted 10 February 2016 - Final revision received 7 February 2017 - Accepted 7 February 2017 - First published online 5 April 2017)
}

\section{Abstract}

An automated respirometer system was used to measure $\mathrm{VO}_{2}$, protein catabolism as ammonia quotient and the energy budget to evaluate whether the crude protein content of a standard protein (SP) diet (42.5\%) or a high-protein (HP) diet (49.5\%) influences metabolism in rainbow trout under challenging intermittent, low dissolved oxygen concentrations. In total, three temperature phases $\left(12,16,20^{\circ} \mathrm{C}\right)$ were tested sequentially, each of which were split into two oxygen periods with $5 \mathrm{~d}$ of unmanipulated oxygen levels (50-70\%), followed by a $5 \mathrm{~d}$ manipulated oxygen period (16.00-08.00 hours) with low oxygen (40-50\%) levels. For both diets, catabolic protein usage was lowest at $16^{\circ} \mathrm{C}$ and was not altered under challenging oxygen conditions. Low night-time oxygen elevated mean daily $\mathrm{VO}_{2}$ by $3-14 \%$ compared with the unmanipulated oxygen period for both diets at all temperatures. The relative change in $\mathrm{VO}_{2}$ and retained energy during the intermittent low oxygen period was smaller for the HP diet compared with the SP diet. However, in absolute terms, the SP diet was superior to the HP diet as the former demonstrated $30-40 \%$ lower protein fuel use rates, higher retained energy (1-4\% digestible energy) and slightly lowered $\mathrm{VO}_{2}$ $(0-8 \%)$ over the range of conditions tested. The decrease in retained energy under low oxygen conditions suggests that there is scope to improve the performance of SP diets under challenging conditions; however, this study suggests that simply increasing the dietary protein content is not a remedy, and other strategies need to be explored.

Key words: Ammonia quotients: Diurnal hypoxia: Energy budget: Oxygen consumption: Re-circulating respirometer system: Retained energy

The water quality within fish farming systems can vary substantially according to a multitude of biotic (e.g. stocking density, feeding rates, microbial loading) and abiotic (e.g. temperature, aeration and water turnover rates) factors. The dissolved oxygen (DO) concentration and temperature are important water quality variables that affect fish metabolism and health ${ }^{(1-5)}$, and the level of DO can change rapidly because of biotic and abiotic factors. Diurnal fluctuations in DO due to photosynthesis, increasing temperature and varying water exchange in net cages or flow through systems are probably one of the most pronounced water-quality changes most farmed fish endure $^{(6-8)}$. Low DO levels are likely to occur during intensive fish $\mathrm{VO}_{2}$ associated with feed ingestion and digestion ${ }^{(9-12)}$. In addition, partial DO depletion or intermittent hypoxia can be amplified at night when phytoplanktons switch from photosynthesis to respiration ${ }^{(13)}$. Furthermore, water exchange through sea net cages varies according to the tidal currents, and slack tides lead to stagnant water periods four times per day. Fish producers in Norway, Chile, Canada and Australia have reported intermittent sub-optimum environmental conditions for salmonid fish production ${ }^{(2)}$; however, the impact of temporary diurnal DO limitations on fish physiology is not often studied ${ }^{(14)}$.

Chronic sub-lethal hypoxia can cause growth reduction due to reduced appetite, alteration of metabolic pathways, re-allocation

Abbreviations: AQ, ammonia quotient; DO, dissolved oxygen; $\mathrm{DO}_{\mathrm{sat}}$, DO saturation; EB, energy budget; EN, energy of non-faecal nitrogen; FCR, feed conversion ratio; HP, high protein; MBW, metabolic body weight; ME, metabolisable energy; MO, manipulated oxygen; RE, retained energy; SDA, specific dynamic action; SGR, specific growth rate; SP, standard protein; TAN, total ammonia nitrogen; TP, temperature phase; UO, unmanipulated oxygen.

* Corresponding author: K. T. Stiller, email stiller@zoology.ubc.ca 
of energy resources, poor assimilation efficiency and prolonged digestion $^{(5)}$. Davis ${ }^{(6)}$ summarised DO threshold levels for rainbow trout (Oncorbynchus mykiss) at various temperatures $\left(8-20^{\circ} \mathrm{C}\right)$ and animal sizes (larva-1.1 kg), and concluded that the effective threshold was in the range of $50-64 \%$ DO saturation $\left(\mathrm{DO}_{\text {sat }}\right)$. Below this level, blood was less oxygenated, circulatory changes such as a slowing heart frequency occur along with reduction of maximum swimming speed, altered RQ, elevated breathing amplitude and elevated buccal pressure ${ }^{(4,15-20)}$. Compared with our understanding about respiratory physiology, much less is known about how chronic or intermittent hypoxia affects digestion and growth in fish. Low oxygen conditions have been observed to alter the specific dynamic action (SDA) of digestion and nutrient assimilation ${ }^{(5)}$.

The production of $1 \mathrm{~kJ}$ of energy via ammonotelic catabolism of protein theoretically requires $2.5 \mathrm{mg}$ more $\mathrm{O}_{2}$ than lipid and $7 \mathrm{mg}$ more $\mathrm{O}_{2}$ than glucose ${ }^{(21)}$, which might mean that protein is metabolised differentially according to DO availability. From an aquaculture perspective, it is more desirable to utilise dietary amino acids for somatic growth rather than as a metabolic fuel source. Carter et $a l^{(2)}$ summarised the strategic needs to study interactions between diet composition and environmental parameters, and suggested that protein metabolism needs particular attention to maximise growth under limiting environmental conditions. This has led to research into special application feeds for 'challenging' conditions such as waters with suboptimal temperature and DO levels ${ }^{(2,22-25)}$. The idea behind such feeds is that the loss of fish condition normally associated with challenging environments (e.g. diurnal fluctuations in DO levels) can be compensated for by tuning the dietary macronutrient and micronutrient compositions. In this study, we attempt to broaden our understanding of fish protein metabolism under diurnal DO variations at different temperatures using juvenile rainbow trout as a model species.

\section{Methods}

\section{Experimental fish and diets}

Before experimentation, animal ethics approval was obtained. Juvenile rainbow trout (weight $=64.9(\mathrm{SD}$ 6.0) g) were purchased from the Forellenzucht Trostadt GbR hatchery (Trostadt, Germany). The experimental fish were acclimated to six respirometer tanks (described below) for 3 weeks before the experiment while being fed a standard commercial diet (Skretting Optiline HE, $4.0 \mathrm{~mm}$, macro nutrient profile: crude protein $43.0 \%$, crude fat $26.0 \%$, ash $6.0 \%$, fibre $3.0 \%$ ) at $12^{\circ} \mathrm{C}$. During the acclimation period, fish were fed by hand in order to determine the absolute amount of feed the animals could ingest. The maximum ingestion quantity was determined to be 1.37 (SD 0.45 ) \% of body weight (BW), and this information was used to set the $1 \% \mathrm{BW}$ ration size in the experiment, a portion size that was completely consumed with no wastage. In trial two, experimental fish groups were fed once per day with isoenergetic diets of varying protein content produced at Skretting ARC Technology Plant (Stavanger, Norway). Table 1 gives the feed composition of the two experimental diets. The standard protein (SP) diet with $42.5 \%$ crude protein was
Table 1. Nutrient composition, digestible energy, ingredients and chemical composition of the test diets. Pellet size $4 \mathrm{~mm}$

\begin{tabular}{lrr}
\hline Diets... & SP & HP \\
\hline Ingredient and proximate composition (g/kg, as-fed) & & \\
Wheat (Svenska Lantmannen, Sweden) & 131 & 81 \\
Maize gluten (Cargill Nordic AS, UK) & 50 & 50 \\
Wheat gluten (Cargill Nordic AS, UK) & 100 & 200 \\
Soya protein concentrate (Imcopa, Brasil) & 300 & 300 \\
Purified cellulose (Arcon AS, Norway) & 9 & 0 \\
NA Fishmeal (Welcon AS, Norway) & 150 & 150 \\
Fish oil Nordic (Norsildmel, Norway) & 236 & 196 \\
AA, vitamin, mineral premix* (Trouw, the Netherlands) & 23 & 22 \\
Yttrium premix (Trouw, the Netherlands) & 1 & 1 \\
Proximate composition (\% as-fed) & & \\
DM & 93.5 & 93.5 \\
Crude protein & 42.5 & 49.5 \\
Crude fat & 27.3 & 23.6 \\
Starch & 8.6 & 6.4 \\
Crude fibre & 2.8 & 2.2 \\
Digestible energy (kJ/g as-fed) & 19.8 & 19.8 \\
Gross energy (kJ/g as-fed) & 23.4 & 23.2 \\
\hline
\end{tabular}

SP, standard protein; HP, high protein; AA, amino acids.

* Recommendation from NRC ${ }^{(26)}$.

similar to existing commercial diets, whereas the high-protein (HP) diet contained $49.5 \%$ crude protein. The HP diet was formulated to be isoenergetic with the SP diet by lowering the fat and starch contents and increasing wheat gluten inclusion (Table 1). Diets were designed to meet amino acid needs of the animals ${ }^{(26)}$. Feeding of the entire daily ration started at 10.00 hour in tank 1 and continued stepwise (12 min for each tank) until all tanks were fed.

\section{Chemical analysis of the diet}

Almost all chemical feed analyses were performed in the Skretting ARC Laboratory, Stavanger. DM was quantified gravimetrically by drying the feed for $18 \mathrm{~h}$ at $105^{\circ} \mathrm{C}$. A Kjeltec 2400 Auto System (FOSS Analytical) was used to determine total nitrogen $(\mathrm{N})$ content for calculating protein content $(\mathrm{N} \times 6 \cdot 25)$. NMR (Maran Ultra NMR; Resonance Instruments Ltd) was used for measuring fat concentration. Starch content was determined according to Mcleary et al. ${ }^{(27)}$, and crude fibre content was determined according to ISO 6865 (ISO 2000). Gross energy was measured in a (isoperibol) bomb calorimeter (Parr 1281) at Nofima BioLab (Fyllingsdalen, Norway).

\section{Experimental setup}

For each diet, three replicate tanks were used.

\section{Temperature phases}

The experiment was divided into three, 16-d rearing temperature phases (TP) $\left(12,16\right.$ and $20^{\circ} \mathrm{C}$, as illustrated in Fig. 1). The sequential testing of temperature over time rather than simultaneous testing of temperature alongside other variables was a constraint imposed by the experimental setup with one water body in the re-circulating respirometer system. Temperature acclimation from 12 to $16^{\circ} \mathrm{C}$ and 16 to $20^{\circ} \mathrm{C}$ was performed in $1^{\circ} \mathrm{C} / \mathrm{d}$ increments over $4 \mathrm{~d}$. 


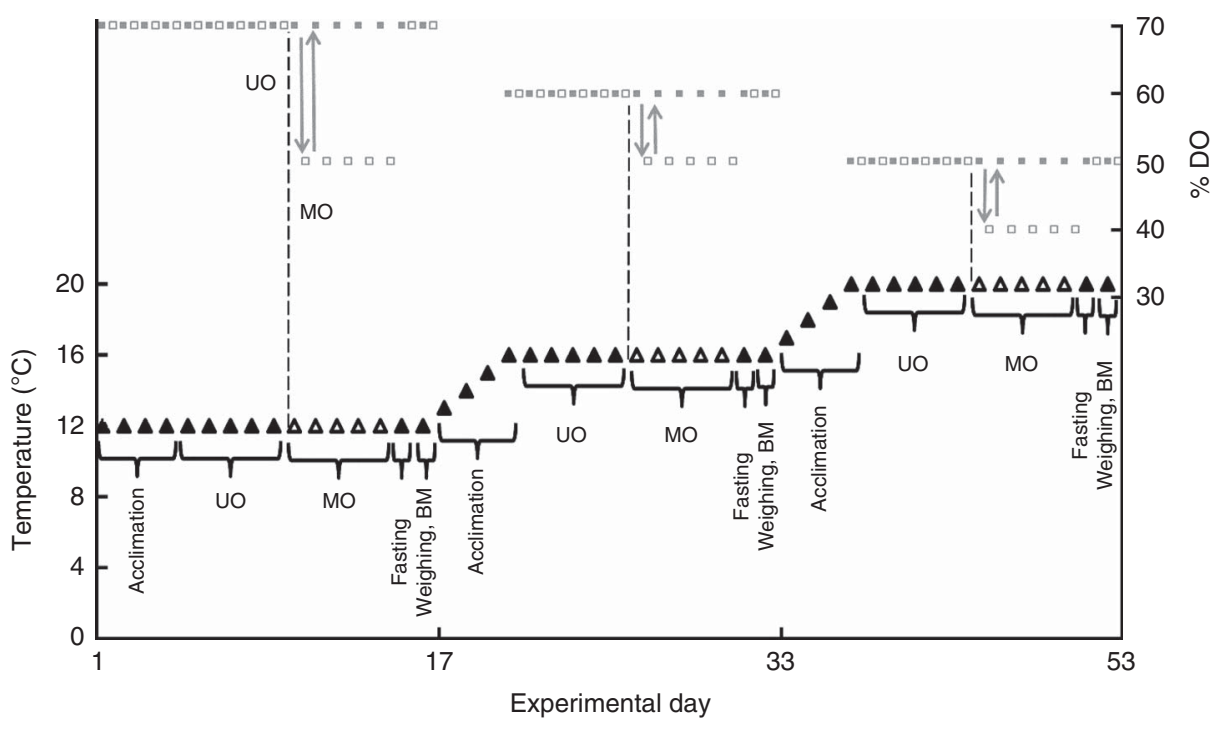

Fig. 1. Experimental setup for the three temperature phases $\left(12,16\right.$ and $\left.20^{\circ} \mathrm{C}\right): 4 \mathrm{~d}$ of acclimation; $5 \mathrm{~d}$ of unmanipulated oxygen (UO) period; $5 \mathrm{~d}$ of manipulated oxygen (MO) period; $1 \mathrm{~d}$ of fasting; and $1 \mathrm{~d}$ of weighing/biomass reduction (BM). Arrows indicate the time of down- and up-regulation of dissolved oxygen saturation during the periods. $\square, 08.00-16.00$ hours; $\square, 16.00-08.00$ hours; $\longleftrightarrow$, dissolved oxygen (DO) manipulation.

\section{Oxygen periods}

Unmanipulated oxygen period. Following temperature acclimation, $5 \mathrm{~d}$ of respirometer measurements were performed at the maximum tank water inflow rate (300 litres/h).

Manipulated oxygen period. Following the unmanipulated oxygen (UO) period, $5 \mathrm{~d}$ of respirometer measurements were performed with decreased nightly water inflow, which created a partial low oxygen challenge for the fish.

To maintain a comparable circular current in the test tanks, an additional pump was installed ${ }^{(28)}$. The target oxygen level during the manipulated oxygen (MO) period was 40-50\% $\mathrm{DO}_{\text {sat }}$, which corresponded to water inflow of 150, 200 and 225-250 litre/h at 12,16 and $20^{\circ} \mathrm{C}$, respectively. The low oxygen challenge was initiated at 16.00 hour using electronic controllers to decrease water inflow. At 08.00 hour the next morning, the water flow rates were increased using the controllers. Once the MO period was completed, fish were fasted for a day and then individual and bulk weighing was performed (Fig. 1).

\section{Fish and biomass}

At the start of every experimental TP, the tank biomass was adjusted to approximately $3.70 \mathrm{~kg}$ via the removal of individuals following individual and bulk weighing. At the beginning of the experiment $\left(12^{\circ} \mathrm{C}\right)$, there were fifty fish with a mean weight of 73.4 (SD 13.0) $\mathrm{g} / \mathrm{tank}$, which was decreased to forty-two fish with a mean weight of $90 \cdot 2$ (SD $21 \cdot 8$ ) g at $16^{\circ} \mathrm{C}$ and thirty-five fish with a mean weight of $105.5(\mathrm{sD} 30 \cdot 0) \mathrm{g} / \mathrm{tank}$ at $20^{\circ} \mathrm{C}$, respectively.

\section{Fish husbandry and respirometer system}

The experiment was performed in a re-circulating aquaculture respirometer system designed for growth studies, which is described in detail by Stiller et al. ${ }^{(28,29)}$. The system consisted of ten tanks (250 litres volume each), of which seven were used for the current experiment, and included mechanical (sedimentation) and biological (trickling filter) water treatment units. The system utilises a flow-through approach to measure respiration, where the water metabolite concentration of each tank is measured sequentially by a suite of water chemistry analysers. Respiration rates are calculated on the basis of differences between test and reference tank metabolite values and water flow rates, with a correction to account for the washout effect. Details about the methods used to calculate respiration rates are given in the study by Stiller et $a l^{(28)}$.

The water chemistry analysis unit measured the following parameters: oxygen $\left(\mathrm{O}_{2}\right)$ concentration (amperometric electrode, dTRANS O2 01; JUMO GmbH \& Co. KG), water pH (intermediate junction electrode, Ionode IJ44; TPS Pty Ltd), temperature (thermocouple), total ammonia nitrogen (TAN) (loop flow orthophtalaldehyde fluorometric autoanalyser, $\mu \mathrm{Mac}$; SYSTEA S.p.A.) and dissolved carbon dioxide $\left(\mathrm{CO}_{2}\right)$ (flow through headspace analyser with non-dispersive IR detection; SubCtech GmbH). Analysers were calibrated daily. Daily data acquisition included twelve measurements per day and tank, corresponding to a 2-h measuring cycle in which every tank was measured successively. The data from six tanks containing fish are presented in this study. Nitrite (mg/l) (Microquant; Merck KGaA) concentration and hardness $\left({ }^{\circ} \mathrm{dH}\right)$ (Aquamerck; Merck KGaA) of the re-circulating water body were recorded daily using commercial test kits.

\section{Growth performance}

Individual body wet weight and whole-tank wet weight (biomass; g) were determined on day 0, 16, 32 and 48, which corresponded to the TP intervals (Fig. 1). All growth performance data were calculated using tank biomass measurements to minimise the error associated with summing multiple individual measurements. This sampling regimen enabled testing of the effects of time/temperature and diet on growth, but not 
oxygen period. After weighing the individuals of a particular tank, the group was placed in a different tank to account for any tank-specific effects. Trout were anaesthetised using tricaine methanesulphonate (MS-222; Sigma-Aldrich) before the weighing procedure started. Specific growth rate (SGR, \% weight gain per day) was calculated from the tank biomass using the formula $\mathrm{SGR}=(\ln ($ end biomass $)-\ln ($ start biomass $)) / 16 \mathrm{~d} \times 100$. Feed conversion ratio (FCR) was calculated using the mass of food ingested and group weight as FCR $=$ feed intake $(\mathrm{g})$ /weight gain $(\mathrm{g})$.

\section{Metabolic data}

$\mathrm{VO}_{2}$ and TAN excretion rates were calculated according to the difference between the tanks housing fish and the fishless reference tank (including microbial background respiration), along with a correction to account for the washout effect, as outlined in Stiller et al. ${ }^{(28)}$. The metabolic rates of a measuring cycle were normalised to a daily specific calculated metabolic $\mathrm{BW}$ (MBW) and expressed as $\mathrm{mg} / \mathrm{h}$ per $\mathrm{kg}^{0.8(30-32)}$. Average daily MBW was estimated via interpolation from the weights recorded at the beginning and at the end of each $\mathrm{TP}$, the daily feed intake and FCR as follows:

$$
\mathrm{MBW}=\left(\begin{array}{c}
(\text { feed intake previous day }(\mathrm{kg}) / \mathrm{FCR} \\
+ \text { biomass previous day }(\mathrm{kg})) / \\
\text { Number of fish in the tank }
\end{array}\right)^{-0 \cdot 8}
$$

The degree of protein utilisation for energy metabolism was estimated using the ammonia quotient $(\mathrm{AQ})^{(33)}$ :

$$
\mathrm{AQ}=\operatorname{Excreted} \mathrm{TAN}(\mathrm{mol}) / \text { consumed }_{2}(\mathrm{~mol}),
$$

where AQ values of 0.27 and 0 correspond to 100 and $0 \%$, respectively, of aerobic energy demand (estimated protein fuel use) met by amino acid catabolism ${ }^{(34)}$.

The last day of the 5-d DO period was used for calculating $\mathrm{VO}_{2}$ and TAN excretion to allow for the maximum acclimation period. The mean values between 22.00-02.00 and 10.0014.00 hours were used for direct comparison between the UO and the MO period of the experiment as these time blocks had the most constant readings within a diurnal curve of metabolite measurements and deemed best for quantitative comparison for day and night response.

\section{Energy budget}

All presented values of the energy budget (EB) were calculated using data collected from the 5th day of each oxygen period (see the 'Oxygen periods' section and Fig. 1) and expressed in $\mathrm{kJ} / \mathrm{kg}^{0 \cdot 8}$ per $\mathrm{d}$ based on an 'as-fed' diet. Calculations of the EB components are as follows.

$\mathrm{VO}_{2}$ and TAN excretion rates were derived from eight measurements taken from a 16-h period (12.00-16.00 and 18.00-06.00 hours), a period that represented the bulk of metabolic activity associated with digestion and assimilation. The eight measurements were used to derive a mean daily $\mathrm{VO}_{2}$ and TAN excretion rate to standardise the time period format. Data collected during periods of maintenance and husbandry activity were excluded for both oxygen periods from the data set as these activities led to inaccurate metabolic measurements. These activities included tank cleaning (06.00-08.00 hours), up-regulation of water flow (08.00-10.00 hours), feed administration (10.00-12.00 hours) and down-regulation of water flow (16.00-18.00 hours).

\section{Gross energy intake per $d$}

Gross energy intake per $\mathrm{d}=\frac{\mathrm{GE}_{\text {diet }}(\mathrm{kJ} / \mathrm{g}) \times \mathrm{FI}(\mathrm{g} / \mathrm{d})}{\mathrm{MBW}\left(\mathrm{kg}^{-0 \cdot 8}\right)}$.

\section{Digestible energy intake}

Digestible energy intake $\left(\mathrm{DE}_{\text {in }}\right)$ per $\mathrm{d}=\frac{\mathrm{DE}_{\mathrm{diet}}(\mathrm{kJ} / \mathrm{g}) \times \mathrm{FI}(\mathrm{g} / \mathrm{d})}{\mathrm{MBW}\left(\mathrm{kg}^{-0 \cdot 8}\right)}$;

Digestible energy $\left(\mathrm{DE}_{\text {diet }}\right)=19.8(\mathrm{SD} 0.2) \mathrm{kJ} / \mathrm{g} ; \mathrm{HP}=19.8(\mathrm{SD} 0.5)$ $\mathrm{kJ} / \mathrm{g}$. Digestible energy was calculated from the energy contents of food and faeces and by applying the indicator (Y) method according to Dietz et al. ${ }^{(35)}$. Faeces were collected by stripping after the main experiment. Because of limited fish numbers, the $\mathrm{DE}_{\text {diet }}$ was only determined at $16^{\circ} \mathrm{C}$. Analyses of dietary, faecal energy and $\mathrm{Y}$ were undertaken at Nofima BioLab (Fyllingsdalen, Norway) and at Skretting ARC (Stavanger, Norway), respectively.

\section{Energy of non-faecal nitrogen}

Energy of non-faecal nitrogen (EN) is defined as the sum of branchial and urinary energy. In this study, EN was calculated as TAN excretion plus an estimated fraction of total nitrogen lost as urea ( $85 \%: 15 \% \mathrm{NH}_{3}$ :urea), the ratio of which was taken from the literature ${ }^{(36-38)}$. The energetic value of this nitrogen mix $(24.6 \mathrm{~kJ} / \mathrm{g})$ was derived from the energetic equivalents of the individual components $(\mathrm{N}=24.9 \mathrm{~kJ} / \mathrm{g}$ and urea $\mathrm{N}=23.1 \mathrm{~kJ} / \mathrm{g})$ and their estimated contributions ${ }^{(35)}$.

\section{Metabolisable energy}

$$
\text { Metabolisable energy }(\mathrm{ME})=\mathrm{DE}_{\mathrm{in}}-\mathrm{EN} \text {. }
$$

\section{Specific dynamic action}

In this study, the additional fasting day that was measured at the end of every TP (see Fig. 1) was used to define the baseline metabolism without the costs imposed by the SDA. To derive the $\mathrm{VO}_{2}$ associated with the SDA, 'the mean daily $\mathrm{VO}_{2}$ rate at fasting' was subtracted from 'the mean daily $\mathrm{VO}_{2}$ rate at the 5 th day of the $\mathrm{UO} / \mathrm{MO}$ period (feeding $\mathrm{VO}_{2}$ rates)' (see Fig. 1). For every TP, 'the mean daily $\mathrm{VO}_{2}$ rate at fasting' was derived in the same way as 'the feeding $\mathrm{VO}_{2}$ rates' (see above for excluded data for the mean daily $\mathrm{VO}_{2}$ rates). The energetic value was derived by using the conversion factor of $13.6 \mathrm{~kJ} / \mathrm{g}$ consumed $\mathrm{O}_{2}{ }^{(39)}$.

\section{Retained energy}

Retained energy $(\mathrm{RE})=\mathrm{ME}-\mathrm{SDA}-$ energy for maintenance.

The energetic costs of the SDA and maintenance were derived by multiplying the appropriate daily $\mathrm{VO}_{2}$ value $(\mathrm{g} / \mathrm{d})$ for each term by a conversion factor $\left(13 \cdot 6 \mathrm{~kJ} / \mathrm{g} \text { consumed } \mathrm{O}_{2}\right)^{(35)}$.

\section{Statistical analysis}

The software package $\mathrm{R}^{(40)}$ was used to statistically evaluate the data. According to the recommendations of Thorarensen $e t a l{ }^{(41)}$, 
data evaluation was based on an appropriate mixed model ${ }^{(42,43)}$. The data were modelled as normally distributed and heteroscedastic. The model included diet (SP, HP), temperature (12, 16, $20^{\circ} \mathrm{C}$ ), time of day (day, night) and oxygen condition (UO, MO), as well as all their interaction terms (2-, 3- and 4-fold), as fixed factors. The fish group and its interaction with time of day were regarded as random factors. In addition, the interactions of the measurement values due to the several levels of experimental day were taken into account. The model was used to investigate differences between treatments via ANOVA and multiple contrast tests ${ }^{(44,45)}$. For the growth variables and whole-body analysis, the same repeated measures approach was used, with a simplified model only including diet, temperature and their interaction term as a fixed factor. Digestibility data were compared using a $t$ test. For all statistical analyses, differences were considered to be significant at $P<0 \cdot 05$.

\section{Results}

\section{Water quality variables}

With the exception of DO concentrations, the water quality during the trial was maintained in a state that would be considered as not harmful for fish health or growth. Nitrite values ranged between 0.2 and $0.3 \mathrm{mg} / \mathrm{l}$, hardness between 5.5 and $8 \cdot 3^{\circ} \mathrm{dH}$, pH between $6 \cdot 0$ and $8 \cdot 1^{(46)}$, dissolved $\mathrm{CO}_{2}<8 \cdot 2 \mathrm{mg} / \mathrm{l}^{(47)}$ and TAN $<0.4 \mathrm{mg} / \mathrm{l}^{(46,48)}$. Fig. 2 gives an overview of the daily pattern of DO concentrations and TAN concentrations of the tanks throughout the trial. The DO tank concentrations decreased substantially with increasing temperature for both the UO period and the MO period as a result of lowered $\mathrm{O}_{2}$ solubility at elevated temperatures. Consequently, DO concentrations at the maximum water inflow of 300 litre/h varied between the three TP, even though the feeding rate and biomass were almost constant for each TP. The effect of a down-regulation of water inflow at 16.00 hour during the MO period can be seen as an abrupt decrease in DO concentration (Fig. 2). The daily pattern of TAN concentration in the test tanks shows a clear increase in $\mathrm{NH}_{3}$ after the 10.00 hour feeding, and was consistently higher for the HP diet (Fig. 2). At the 16 and $20^{\circ} \mathrm{C} \mathrm{TP}$, TAN concentrations slightly increased over the experimental days. The representative DO concentrations at the last (5th) day of each DO period (08.0016.00 hours) were

$$
\begin{aligned}
& \mathrm{UO}=7 \cdot 6 \pm 0.3 \mathrm{mg} / \mathrm{l}\left(70 \% \mathrm{DO}_{\text {sat }}\right) ; \mathrm{MO}=7 \cdot 2 \pm 0.3 \mathrm{mg} / \mathrm{l}\left(70 \% \mathrm{DO}_{\text {sat }}\right) \\
& \text { at } 12^{\circ} \mathrm{C} \\
& \mathrm{UO}=5 \cdot 7 \pm 0.2 \mathrm{mg} / \mathrm{l}\left(60 \% \mathrm{DO}_{\text {sat }}\right) ; \mathrm{MO}=5 \cdot 4 \pm 0 \cdot 2 \mathrm{mg} / \mathrm{l}\left(60 \% \mathrm{DO}_{\text {sat }}\right) \\
& \text { at } 16^{\circ} \mathrm{C} \text { and } \\
& \mathrm{UO}=4.6 \pm 0.1 \mathrm{mg} / \mathrm{l}\left(50 \% \mathrm{DO}_{\text {sat }}\right) ; \mathrm{MO}=4 \cdot 1 \pm 0.2 \mathrm{mg} / \mathrm{l}\left(50 \% \mathrm{DO}_{\text {sat }}\right) \\
& \text { at } \left.20^{\circ} \mathrm{C} \text { (Fig. } 2\right) \text {. }
\end{aligned}
$$

At night (16.00-08.00 hours), the DO values were

$\mathrm{UO}=7.7 \pm 0.2 \mathrm{mg} / \mathrm{l}\left(70 \% \mathrm{DO}_{\text {sat }}\right) ; \mathrm{MO}=5.0 \pm 0.3 \mathrm{mg} / \mathrm{l}\left(50 \% \mathrm{DO}_{\mathrm{sat}}\right)$ at $12^{\circ} \mathrm{C}$,

$\mathrm{UO}=6 \cdot 1 \pm 0.3 \mathrm{mg} / \mathrm{l}\left(60 \% \mathrm{DO}_{\text {sat }}\right) ; \mathrm{MO}=4.5 \pm 0 \cdot 2 \mathrm{mg} / \mathrm{l}\left(50 \% \mathrm{DO}_{\text {sat }}\right)$

at $16^{\circ} \mathrm{C}$ and $\mathrm{UO}=4.7 \pm 0.2 \mathrm{mg} / \mathrm{l} \quad\left(50 \% \quad \mathrm{DO}_{\mathrm{sat}}\right) ; \mathrm{MO}=3.4 \pm$ $0 \cdot 2 \mathrm{mg} / \mathrm{l}\left(40 \% \mathrm{DO}_{\text {sat }}\right)$ at $20^{\circ} \mathrm{C}$.

There were no obvious differences in fish behaviour observed at the different DO periods or TP.

\section{Growth performance}

As growth data were only evaluated within the TP, it was not possible to compare growth rates between the UO period and the MO period. Within each TP, the type of diet did not lead to any significant differences in weight gain, SGR or FCR (all comparisons $P>0.05)$. Despite a lack of difference between diets, there were clear differences over time as the fish grew and were exposed to different TP. The SGR decreased from 1.11 to $0.71-0.75 \% / \mathrm{d}$, and the FCR increased from 0.78 to $1 \cdot 20-1 \cdot 27$ (Table 2).

\section{Metabolic variables}

\section{Oxygen}

Fig. 2 summarises the diurnal pattern in DO concentration throughout the experiment. The large changes in DO concentration

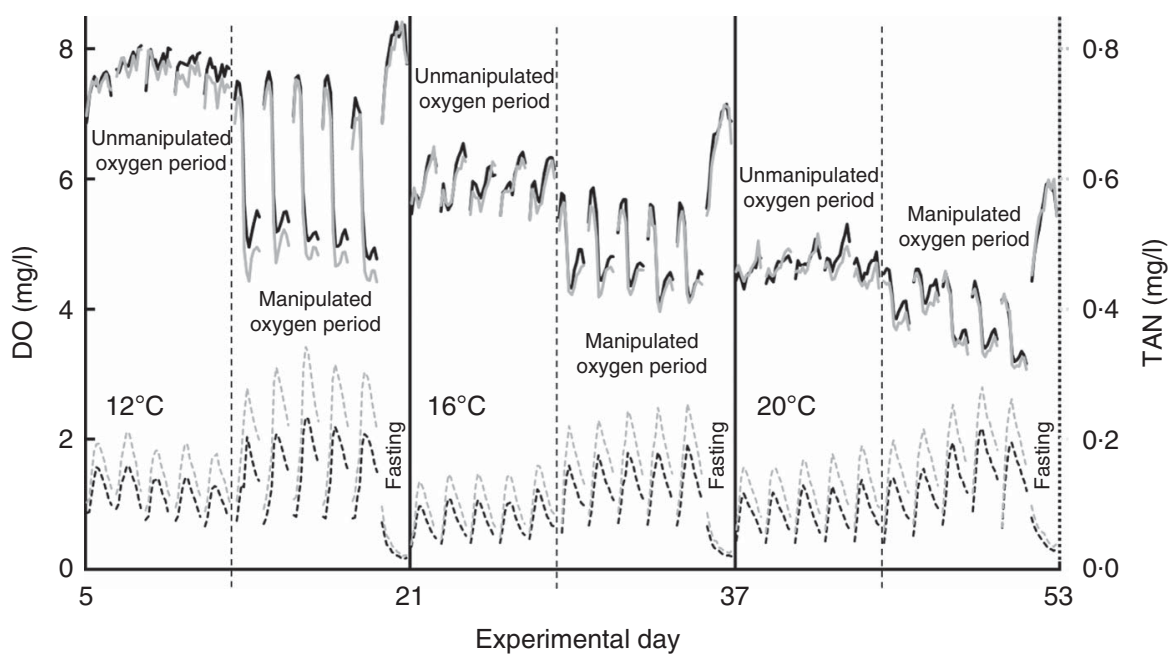

Fig. 2. Dissolved oxygen (DO) and total ammonia nitrogen (TAN) concentrations in the test tanks stocked with rainbow trout fed a standard protein diet $(\mathrm{SP}=42.5 \%$ crude protein) and a high-protein diet ( $\mathrm{HP}=49.5 \%$ crude protein). Data were recorded at three temperatures and under an unmanipulated oxygen period and a manipulated oxygen period. Fasting days are also reported. , DO SP diet; , DO HP diet; , TAN SP diet; -...-- , TAN HP diet. 
within each temperature block shown in Fig. 2 are due to spontaneous activity associated with feeding and SDA, and the effect of fasting is evident in all profiles as a drastic increase in DO concentration. Elevated temperatures were seen to decrease the DO concentration. The DO concentration profiles of the two diets broadly overlapped; however, at $12^{\circ} \mathrm{C}$, the HP diet was generally below the SP diet (Fig. 2).

Table 3 compares the day and night mass-specific $\mathrm{VO}_{2}$ on the final feeding day of each of the two DO periods and the three TP. Temperature had a strong effect on $\mathrm{VO}_{2}\left(F_{2,40}=39 \cdot 7\right.$, $P<0.01$ ), where a $4^{\circ} \mathrm{C}$ rise in temperature led to an increase in $\mathrm{VO}_{2}$ of approximately $20 \mathrm{mg} / \mathrm{kg}^{0.8}$ per h, which was equivalent to a $25-30 \%$ elevation. The DO period was also observed to have a significant effect on $\mathrm{VO}_{2}\left(F_{1,40}=4.4, P=0.04\right)$. There was a general trend for a $3-14 \%$ higher mean $\mathrm{VO}_{2}$ in the $\mathrm{MO}$ period compared with the UO period for the same diet and time of day; however, the differences were only statistically significant at $16^{\circ} \mathrm{C}$ for both diets and at $20^{\circ} \mathrm{C}$ for the SP diet (see Table 3). By comparing the night-time DO periods for the SP diet, there was $11 \%$ higher $\mathrm{VO}_{2}$ in the $\mathrm{MO}$ period for 16 and $20^{\circ} \mathrm{C}$. This difference in $\mathrm{VO}_{2}$ could not be detected for trout fed the HP diet, where the highest difference was $6 \%$. Overall, the statistical model did not detect a significant difference between daytime and night-time $\mathrm{VO}_{2}\left(F_{1,4}=5 \cdot 7, P=0.08\right)$. As was observed in the continuous time plot of Fig. 2, the mean $\mathrm{VO}_{2}$ of fish fed the SP diet tended to be lower (0-8\%) than that of fish fed the HP diet under equivalent conditions (Table 3); however, this difference was not statistically significant $\left(F_{1,4}=3 \cdot 2\right.$, $P=0 \cdot 15)$. All two- and three-way interaction terms for $\mathrm{VO}_{2}$ were non-significant $(P>0 \cdot 28)$.

\section{Ammonia}

Fig. 2 summarises the diurnal pattern in TAN concentration in the test tanks throughout the experiment. The protein concentration difference of the two diets at $1 \%$ BW feeding had a noticeable effect on TAN concentration in the tanks, and thus protein usage in catabolism. Before feeding, TAN concentration was at its lowest daily value. After feeding at 10.00 hour, TAN increased steadily for 8-10 h until it peaked at approximately twice the prefeeding value. TAN concentration in the tanks was consistently higher for fish fed the HP diet. The decreasing values during fasting led to equally low values between the diets (Fig. 2).

$\mathrm{NH}_{3}$ excretion rate was standardised to $\mathrm{VO}_{2}$ rate to derive the $\mathrm{AQ}$ and estimated protein catabolism rates without urea and other N-fractions. Table 4 compares the day and night AQ on the final feeding day of each of the two DO periods and the three TP. Night-time AQ values were consistently higher (Table 4) and significantly different to daytime AQ values $\left(F_{1,4}=81 \cdot 8, P<0 \cdot 01\right)$, reflecting the elevated nightly TAN excretion observed in Fig. 2. Statistical analyses indicated that temperature had a significant effect on AQ $\left(F_{2,38}=7 \cdot 1, P<0 \cdot 01\right)$, DO period had a significant effect on AQ $\left(F_{1,38}=5.9, P=0.02\right)$ and temperature and DO period had a significant interaction $\left(F_{2,38}=13 \cdot 4, P<0 \cdot 01\right)$. The catabolic protein fuel use tended to be lowest at $16^{\circ} \mathrm{C}$ and higher at 12 and $20^{\circ} \mathrm{C}$ (Table 4). Low nightly DO concentrations tended to not significantly increase the rate of protein fuel use at 12 and $20^{\circ} \mathrm{C}$. Statistically significant differences in DO period were only 
Table 3. Mass-specific $\mathrm{VO}_{2}\left(\mathrm{mg} / \mathrm{kg}^{0.8}\right.$ per h) of rainbow trout fed a standard protein diet $(\mathrm{SP}=42.5 \%$ crude protein) and a high-protein diet ( $\mathrm{HP}=49.5 \%$ crude protein) under an unmanipulated oxygen (UO) period and a manipulated (MO) period $\dagger$

(Mean values and standard deviations)

\begin{tabular}{|c|c|c|c|c|c|c|c|c|c|c|c|c|}
\hline$\frac{\text { Oxygen periods }}{\text { Diets }}$ & \multicolumn{2}{|c|}{ SP } & \multicolumn{2}{|c|}{$\mathrm{HP}$} & SP v. HP & \multicolumn{2}{|c|}{ SP } & \multicolumn{2}{|c|}{$\mathrm{HP}$} & $\mathrm{SP} v . \mathrm{HP}$ & SP & $\mathrm{HP}$ \\
\hline \multicolumn{13}{|c|}{ Day (10.00-14.00 hours) } \\
\hline $12^{\circ} \mathrm{C}$ & $119 \cdot 8^{\mathrm{a}}$ & 2.4 & $128 \cdot 6^{\mathrm{a}}$ & 8.4 & - & $128.9^{\mathrm{a}}$ & $5 \cdot 8$ & $139 \cdot 3^{a}$ & $16 \cdot 3$ & - & - & - \\
\hline $16^{\circ} \mathrm{C}$ & $146 \cdot 9^{b}$ & 4.8 & $152 \cdot 0^{\mathrm{b}}$ & 4.4 & - & $156 \cdot 0^{\mathrm{b}}$ & 1.8 & $162 \cdot 8^{\mathrm{b}}$ & 2.3 & - & * & * \\
\hline $12^{\circ} \mathrm{C}$ & $111.8^{a}$ & $5 \cdot 7$ & $122 \cdot 2^{a}$ & $6 \cdot 2$ & - & $118.5^{\alpha} \ddagger$ & 1.8 & $125 \cdot 8^{\alpha} \neq$ & 3.2 & - & - & - \\
\hline $16^{\circ} \mathrm{C}$ & $128 \cdot 0^{\beta}$ & 1.2 & $134 \cdot 6^{a}$ & $6 \cdot 3$ & - & $142 \cdot 6^{\beta} \neq$ & $2 \cdot 8$ & $142 \cdot 3^{\beta} \neq$ & $3 \cdot 1$ & _- & * & * \\
\hline $20^{\circ} \mathrm{C}$ & $143 \cdot 2^{\gamma}$ & 8.2 & $155 \cdot 6^{\beta}$ & $5 \cdot 6$ & - & $158 \cdot 7^{\ddagger} \ddagger$ & 1.0 & $162 \cdot 2^{\gamma} \ddagger$ & 2.9 & - & * & - \\
\hline
\end{tabular}

a,b,c for day, ${ }^{a, \beta, \gamma}$ for night: mean values within a column with unlike superscript letters are significantly different, and between-column differences are shown with * $(P<0.05)$.

† Data are divided into daytime (10.00-14.00 hours) and night-time (22.00-02.00 hours) measurements. Day and night data were used from the 5th day of the UO and MO periods from every temperature phase. Values are means of triplicate tanks measured on the 5th day of each test regimen. Dissolved oxygen saturation in the test tanks: UO day and night and $\mathrm{MO}$ day: $12^{\circ} \mathrm{C}=70 \%, 16^{\circ} \mathrm{C}=60 \%, 20^{\circ} \mathrm{C} 50 \%$.

‡ MO night: $12^{\circ} \mathrm{C}=50 \%, 16^{\circ} \mathrm{C}=50 \%, 20^{\circ} \mathrm{C}=40 \%$.

Table 4. Estimated protein fuel use (\% of energy aerobic energy expenditure) of rainbow trout fed a standard protein diet (SP $=42.5 \%$ crude protein) and a high-protein diet (HP $=49.5 \%$ crude protein) under an unmanipulated oxygen (UO) and manipulated oxygen (MO) period $\dagger$

(Mean values and standard deviations)

\begin{tabular}{|c|c|c|c|c|c|c|c|c|c|c|c|c|}
\hline \multirow{3}{*}{$\frac{\text { Oxygen periods }}{\text { Diets }}$} & \multicolumn{5}{|c|}{ UO } & \multicolumn{5}{|c|}{$\mathrm{MO}$} & \multicolumn{2}{|c|}{ UO v. MO } \\
\hline & \multicolumn{2}{|c|}{ SP } & \multicolumn{2}{|c|}{$\mathrm{HP}$} & \multirow[b]{2}{*}{$\mathrm{SP} v . \mathrm{HP}$} & \multicolumn{2}{|c|}{$\mathrm{SP}$} & \multicolumn{2}{|c|}{$\mathrm{HP}$} & \multirow[b]{2}{*}{ SP v. HP } & \multirow[t]{2}{*}{$\mathrm{SP}$} & \multirow[t]{2}{*}{$\mathrm{HP}$} \\
\hline & Mean & $\mathrm{SD}$ & Mean & SD & & Mean & SD & Mean & SD & & & \\
\hline \multicolumn{13}{|c|}{ Day (10.00-14.00 hours) } \\
\hline $12^{\circ} \mathrm{C}$ & $20 \cdot 4^{a}$ & $2 \cdot 1$ & $27 \cdot 6^{a}$ & $1 \cdot 8$ & - & $18 \cdot 8^{a}$ & $1 \cdot 8$ & $25 \cdot 8^{a, b}$ & 1.9 & * & - & - \\
\hline $16^{\circ} \mathrm{C}$ & $15 \cdot 8^{b}$ & 0.2 & $20 \cdot 9^{b}$ & $1 \cdot 0$ & - & $19 \cdot 0^{a}$ & 1.0 & $24 \cdot 1^{\mathrm{a}}$ & $1 \cdot 8$ & - & * & * \\
\hline $20^{\circ} \mathrm{C}$ & $19 \cdot 0^{a, b}$ & $1 \cdot 2$ & $25 \cdot 8^{a}$ & 0.8 & - & $21 \cdot 3^{a}$ & 0.7 & $28 \cdot 4^{b}$ & 3.6 & - & - & - \\
\hline \multicolumn{13}{|c|}{ Night (22.00-02.00 hours) } \\
\hline $12^{\circ} \mathrm{C}$ & $25 \cdot 2^{a}$ & 1.7 & $35 \cdot 6^{a}$ & 1.9 & * & $24 \cdot 4^{a} \ddagger$ & 1.4 & $34.8^{a} \ddagger$ & 1.7 & * & - & - \\
\hline $16^{\circ} \mathrm{C}$ & $19 \cdot 5^{\beta}$ & 0.8 & $26 \cdot 7^{\beta}$ & 1.5 & * & $21 \cdot 1^{\beta} \ddagger$ & 0.9 & $30 \cdot 3^{\beta} \neq$ & 1.6 & * & - & * \\
\hline $20^{\circ} \mathrm{C}$ & $22 \cdot 1^{\mathrm{a}, \beta}$ & 0.6 & $31 \cdot 2^{\beta}$ & $1 \cdot 7$ & * & $24 \cdot 2^{\alpha, \beta} \ddagger$ & 0.8 & $31 \cdot 8^{a, \beta} \ddagger$ & 0.5 & * & - & - \\
\hline
\end{tabular}

a,b,c for day, ${ }^{a, \beta, y}$ for night: mean values within a column with unlike superscript letters were significantly different, and between-column differences are shown with * $(P<0.05)$.

† Data are divided into daytime (10.00-14.00 hours) and night-time (22.00-02.00 hours) measurements. Values are mean of triplicate tanks measured on the 5th day of each test regimen. Dissolved oxygen saturation in the test tanks: UO day and night and MO day: $12^{\circ} \mathrm{C}=70 \%, 16^{\circ} \mathrm{C}=60 \%, 20^{\circ} \mathrm{C} 50 \%$.

‡ MO night: $12^{\circ} \mathrm{C}=50 \%, 16^{\circ} \mathrm{C}=50 \%, 20^{\circ} \mathrm{C}=40 \%$.

detected at $16^{\circ} \mathrm{C}$, where the manipulated DO regimen increased AQ from $15 \cdot 8-26 \cdot 7$ to $19 \cdot 0-30 \cdot 3 \%$ (corresponding to an $8-17 \%$ relative increase, Table 4). Temperature and time of day also had a significant interaction $\left(F_{2,38}=5 \cdot 5, P<0 \cdot 01\right)$, where the highest AQ values for each diet were recorded at night-time at the highest temperature (Table 4). Comparison of the AQ shown in Table 4 suggests that diet had a marked and consistent effect on protein fuel use, as within each temperature and DO period trout fed the HP diet consistently used more protein for aerobic metabolism compared with the SP diet. Statistical analyses confirmed that dietary protein content of the diet had a significant effect on the AQ $\left(F_{1,4}=36 \cdot 0, P<0 \cdot 01\right)$, and post hoc testing indicated that the significant differences were mainly present during the night; however, the interaction term for diet and time of day $\left(F_{1,4}=5 \cdot 7\right.$, $P=0.08)$ was not significant at a 0.05 threshold. The metabolic protein usage was 30-40\% higher for fish fed the HP diet compared with the SP diet over the test temperature range. Other than those already mentioned, no other two- or three-way interaction terms were significant $(P>0 \cdot 25)$.

\section{Energy budget}

\section{Energy of non-faecal nitrogen}

Diet had a significant effect on energy of EN $\left(F_{1,4}=334 \cdot 8\right.$, $P<0.01$ ), which was $26-34 \%$ higher for the HP diet compared with the SP diet. Temperature had a significant effect on EN $\left(F_{2,20}=136 \cdot 8, P<0 \cdot 01\right)$, and temperature and DO period had a combined significant interaction $\left(F_{2,20}=36 \cdot 1, \quad P<0 \cdot 01\right)$. Although there was no substantial change in EN between 12 and $16^{\circ} \mathrm{C}$, there was a $20-26 \%$ increase between 16 and $20^{\circ} \mathrm{C}$. The DO period did not have a significant effect on EN $\left(F_{1,20}=3.4, P<0 \cdot 08\right)$ and no other two- or three-way interaction terms were significant $(P>0 \cdot 09)$ (Table 5$)$.

\section{Metabolisable energy}

Statistical analysis indicated that diet $\left(F_{1,4}=60.4, P<0.01\right)$, temperature $\left(F_{2,20}=194 \cdot 0, P<0 \cdot 01\right)$, DO period $\left(F_{1,20}=166 \cdot 6\right.$, $P<0.01)$, and temperature and DO period interaction $\left(F_{2,20}=26 \cdot 3, P<0 \cdot 01\right)$ had a significant effect on the resulting ME. 
Table 5. Energy budget ( $\mathrm{kJ} / \mathrm{kg}^{0.8}$ per d) of rainbow trout fed a standard protein diet (SP, $42.5 \%$ crude protein) and a high-protein diet (HP, $49.5 \%$ crude protein) under an unmanipulated oxygen (UO) period and a manipulated oxygen (MO) period†

(Mean values and standard deviations of triplicate feeding groups)

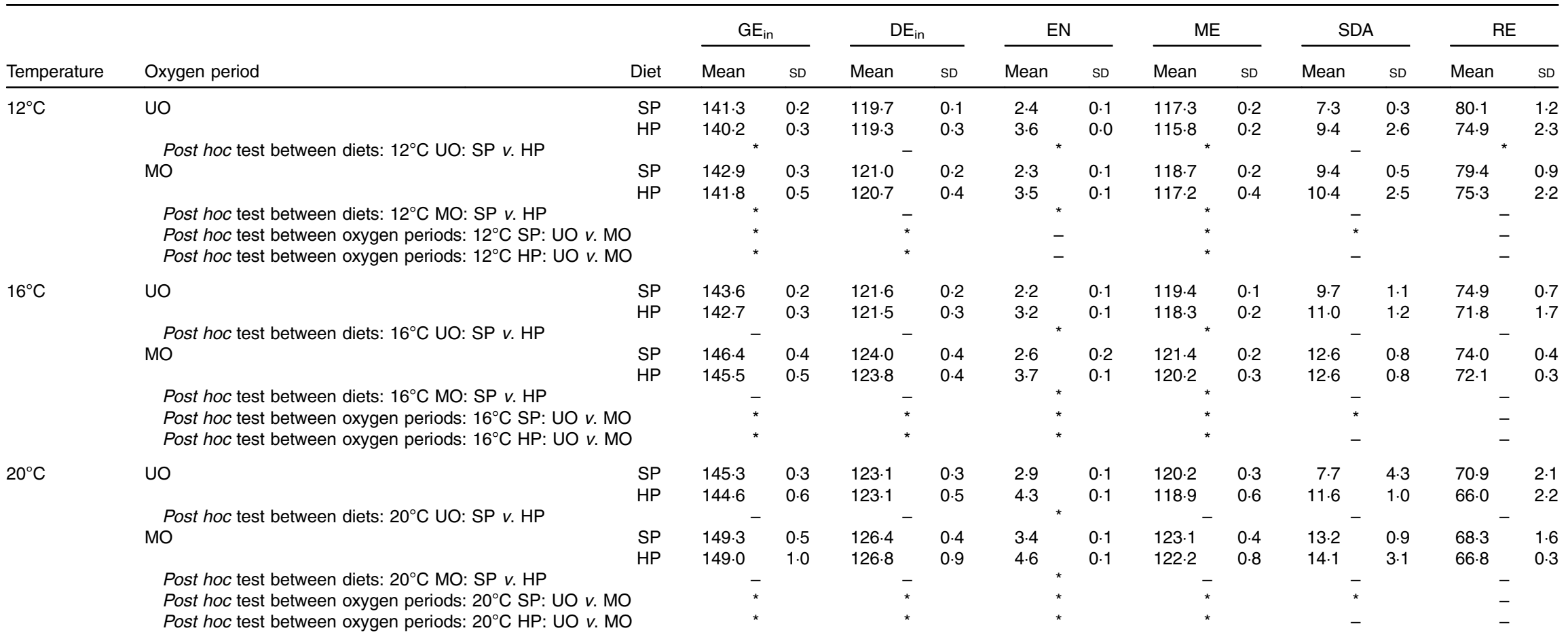

$G E_{i n}$, gross energy intake; $D E_{\text {in }}$, digestible energy intake; $E N$, energy of non-faecal nitrogen; ME, metabolisable energy; SDA, relative specific dynamic action; RE, retained energy.

* Significantly different for diet and oxygen period $(P<0.05)$.

t The experiment was divided into three rearing temperature phases $\left(12,16\right.$ and $\left.20^{\circ} \mathrm{C}\right)$. Data were used from the fifth measurement day of each oxygen period at the three temperatures. Calculated values presented as mean from eight

measurements taken over a 16-h period (12.00-16.00 and 18.00-06.00 hours; see 'Energy budget' section for details). The energy budgets were calculated with the diet as-fed. Dissolved oxygen concentrations in the test tanks were

as follows: $\mathrm{UO}$ and $\mathrm{MO}$ day $12^{\circ} \mathrm{C}=70 \%, 16^{\circ} \mathrm{C}=60 \%, 20^{\circ} \mathrm{C}=50 \%$, MO night: $12^{\circ} \mathrm{C}=50 \%, 16^{\circ} \mathrm{C}=50 \%, 20^{\circ} \mathrm{C}=40 \%$. 


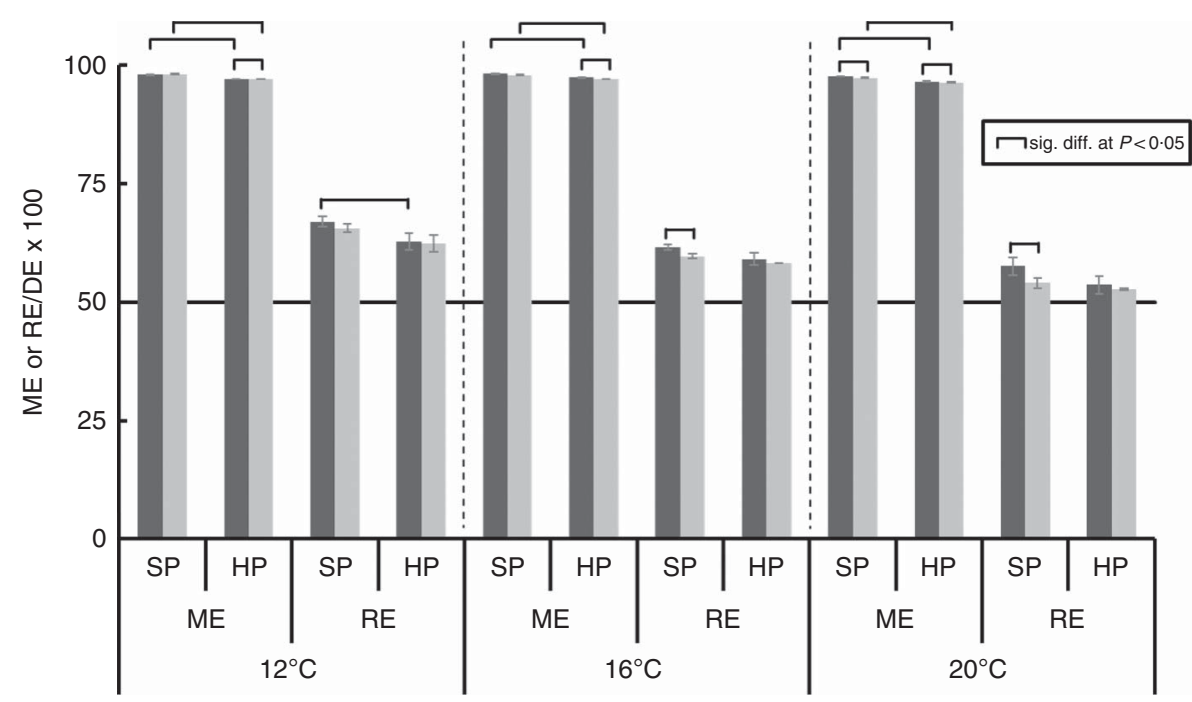

Fig. 3. Metabolisable energy $(M E)$ and retained energy $(R E)$ as percentage (ME/DE $\times 100$ and $R E / D E \times 100)$ of digestible energy $(D E)$ of rainbow trout fed a standard protein diet $(\mathrm{SP}=42.5 \%$ crude protein) and a high-protein diet $(\mathrm{HP}=49.5 \%$ crude protein) reared under an unmanipulated oxygen $(\square)$ period and a manipulated oxygen $(\square)$ period. Values are calculated as means between 12.00 and 06.00 hours from the 5 th day of each oxygen period and experimental temperature. Significant differences $(P<0.05)$ between group means for diet and oxygen period for each temperature are shown with horizontal bars.

The ME was approximately $1 \%$ lower for the HP diet, it decreased by $1-4 \%$ between 12 and $20^{\circ} \mathrm{C}$, and was $1-3 \%$ higher during the MO period. No other variables or two- or three-way interaction terms were significant $(P>0 \cdot 29)$ (Table 5).

\section{Specific dynamic action}

Although the SDA tended to be lower for the SP diet, none of the analysed variables had a significant effect on SDA $(P>0.06)$. The SDA during the MO period was $22 \%\left(12^{\circ} \mathrm{C}\right), 23 \%\left(16^{\circ} \mathrm{C}\right)$ and $42 \%$ $\left(20^{\circ} \mathrm{C}\right)$ higher for the SP diet and $10 \%\left(12^{\circ} \mathrm{C}\right), 13 \%\left(16^{\circ} \mathrm{C}\right)$ and $18 \%$ $\left(20^{\circ} \mathrm{C}\right)$ for the HP diet compared with the UO period (Table 5 ).

\section{Retained energy}

Diet $\left(F_{1,4}=13 \cdot 3, P=0.02\right)$ and temperature $\left(F_{2,20}=17 \cdot 2, P<0.01\right)$ had a significant effect on RE; however, the DO period did not differ $\left(F_{1,20}=0 \cdot 3, P=0.59\right)$. The RE data showed a large decrease (13-15\%) between 12 and $20^{\circ} \mathrm{C}$, and the HP diet resulted in 3-7\% lower RE than the SP diet. All other variables and interactions had no significant effect on $\mathrm{RE}(P>0 \cdot 17)$ (Table 5).

The EB data are represented in Fig. 3, which compare the metabolised and retained energy when the data are normalised to the quantity of digestible energy consumed ${ }^{(31)}$. The normalised RE decreased markedly with increasing temperature (a maximum 12\% absolute decrease), whereas normalised ME only decreased slightly $(<1 \%)$ over the same range (Fig. 3). Although the MO period tended to result in lower normalised ME and RE, diet was observed to have a larger effect. The HP diet consistently resulted in approximately $1 \%$ lower normalised ME and RE (1-4\%) values compared with the SP diet (Fig. 3).

\section{Discussion}

The experiment described in the present study used the common approach $^{(8,22,49,50)}$ of down-regulating water throughput rate to create a DO challenge. These studies have the disadvantage that many water quality factors other than DO change simultaneously as the turnover through a tank decreases. The present study used high-precision $\mathrm{CO}_{2}$ and $\mathrm{NH}_{3}$ analysers to measure whether these key water quality variables exceeded thresholds that would likely influence the metabolism of the animals during periods of reduced water exchange. It was determined that $\mathrm{CO}_{2}$ and TAN concentrations in the present study were $<8.2 \mathrm{mg} / \mathrm{l}$ dissolved $\mathrm{CO}_{2}^{(44)}$ and $<0.4 \mathrm{mg} / 1 \mathrm{TAN}^{(3)}$, which likely did not affect the fish ${ }^{(46,51)}$. As a result, main variables to consider in terms of the results were the target variables of temperature, diet and DO.

The animals in our study acclimated fast, and their metabolism quickly stabilised to new temperature conditions and the moderately challenging night-time DO conditions. This observation is in line with the wide temperature tolerance reported for the species $^{(52)}$ and their ability to endure moderately hypoxic waters ${ }^{(53)}$. There was no difference in growth rate, feed intake and FCR observed between the two diets; however, such differences would not likely be observable over a short period such as 2 weeks with two isoenergetic diets of nearly identical digestive profile that would generally fulfil nutritional requirements. The poorer SGR and FCR observed with increasing temperature and experimental time was likely attributable to temperature effects ${ }^{(54)}$. Metabolic rate increases with temperature, so that beyond an optimal range elevated energy demand diverts nutrients towards fuel pathways rather than growth ${ }^{(55-57)}$. This pattern was observed in the present study, where metabolic rate increased with temperature and growth and normalised retained energy decreased.

Fish fed the HP diet tended to have slightly higher (0-8\%) $\mathrm{VO}_{2}$ than animals fed the SP diet, and the EB analysis suggests that the energy retained by fish fed the HP diet was consistently lower than that of fish reared on the SP diet, although the difference was small in magnitude. The elevated $\mathrm{VO}_{2}$ rate and lower energy retention observed in fish fed the HP diet 
compared with the SP diet may be related to differences in metabolic fuel use. The production of $1 \mathrm{~kJ}$ of energy via ammonotelic catabolism of protein theoretically requires $74.1 \mathrm{mg} \mathrm{O}_{2}$, whereas lipid and glucose require only 71.6 and $67 \cdot 1 \mathrm{mg} \mathrm{O}$, respectively ${ }^{(21)}$. The SP diet had higher inclusion rates of lipid and starch (to maintain comparable energy value with the HP diet), and these fuels require less $\mathrm{O}_{2}$ for oxidative catabolism, and thus it may have been that fish metabolising the SP diet were utilising a fuel mix that was less oxygen demanding than fish metabolising the HP diet. Saravanan ${ }^{(24)}$ reported that diet-induced oxygen use declined with increasing dietary fat energy for rainbow trout, which is congruent with findings from the present study.

The protein fuel utilisation of fish fed the HP diet at $16^{\circ} \mathrm{C}$ is comparable with those reported by Alsop \& Wood ${ }^{(58)}$ (approximately $25 \%$ ) for juvenile rainbow trout on a similar diet and ration size $(50 \%$ protein diet, $1 \% \mathrm{BW}$ per day). Alsop \& Wood $^{(58)}$ measured ammonia and urea $1 \mathrm{~h}$ before feeding and $8 \mathrm{~h}$ after feeding, and reported protein fuel utilisation as a daily mean value. Analysis of the daily $\mathrm{NH}_{3}$ excretion pattern curves from the present study indicate that Alsop \& $\operatorname{Wood}^{(58)}$ likely sampled time points that represented the minimum and maximum excretion rates. Estimated protein catabolism rates were comparable between the studies (for the HP diet, a comparable diet to that used by Alsop \& $\operatorname{Wood}^{(58)}$ ). The present study did not measure urea excretion, which may indicate that true protein catabolism rates of fish in the present study may be higher ${ }^{(38)}$; however, the analysis of the present study excluded pre-feeding ammonia excretion rates values, which complicates direct comparison of absolute rates between studies.

The AQ data of this experiment suggested that fish fed the HP diet were metabolising more protein as a fuel source than fish fed SP diet. In combination with a lower RE, it appears that the $7 \%$ higher protein inclusion in the HP diet was used in catabolism and was not invested in improved growth. Alsop \& Wood $^{(58)}$ have suggested that the use of protein as a fuel source is strongly dependent on protein intake quantity and quality ${ }^{(59)}$. The results from our study support this notion, namely that dietary protein supply beyond an upper limit increases dietary protein catabolism. The preferred metabolic pathways are probably fixed ontogenetically ${ }^{(2,60)}$, and protein is used as a fuel depending on the dietary content, quality and variation from the optimum environmental temperature ${ }^{(61)}$. The finding of no observable advantage of a HP supply under challenging conditions aligns with a study of Atlantic salmon (Salmo salar) fed diets from 41 to $45 \%$ crude protein at about $60 \% \mathrm{DO}_{\text {sat }}{ }^{(2)}$. Other studies with barramundi (Lates calcarifer) report that a $\mathrm{HP}$ diet reduces the impact of growth retardation at higher temperatures ${ }^{(2,23)}$

Glencross $^{(22)}$ concluded that protein utilisation at low DO levels was independent of the DO content of the surrounding water, which agrees with the AQ measurements in our experiment. The juvenile rainbow trout were not observed to consistently catabolise more protein under low DO conditions for either diet. In addition, although feed intake is a key variable known to be affected by low DO conditions via retardation of the SDA and reduced gut throughput rate $^{(2,49,50,62,63)}$, the low night-time DO period in the present study was not observed to have any effect on the feed intake on the morning of the following day. However, the restricted ration size used in the present study would be considered low for rainbow trout ${ }^{(54)}$ and there may be effects of intermittent DO on feed intake at higher ration sizes or with unrestricted feeding.

The MO period with low night-time DO elevated mean daily $\mathrm{VO}_{2}$ by $3-14 \%$ above that recorded for the UO period for both diets and all temperatures. The higher $\mathrm{VO}_{2}$ may be attributable to physiological and behavioural actions that were required to cope with suboptimal DO conditions, such as elevated swimming, heart and ventilation rate and prolonged digestion $^{(4,5,15-19,64)}$. The MO challenge resulted in an $11 \%$ higher night-time $\mathrm{VO}_{2}$ above that recorded for UO periods at 16 and $20^{\circ} \mathrm{C}$ for fish fed the SP diet, whereas fish fed the HP diet increased $\mathrm{VO}_{2}$ by a maximum of $6 \%$ under equivalent conditions. The results of the EB indicated a small but consistent reduction in RE under intermittent low DO conditions, which may lead to a loss of growth performance over longer periods than that tested in this study. Increasing temperatures led to bigger differences in RE between the DO periods for fish fed the SP diet compared with the HP diet, and taken together with these aforementioned differences suggest that the HP diet had some effect in moderating the physiological changes associated with challenging DO conditions and temperature variation. However, a HP diet was also observed to generally elevate $\mathrm{VO}_{2}$ and have lower RE than the SP diet for all conditions tested, meaning the HP diet gave no net benefit under challenging conditions.

\section{Conclusion}

The aim of the present study was to observe any changes in metabolic rate and protein fuel use in juvenile rainbow trout under different temperature, diet and DO periods. Further, we aimed to evaluate whether a HP diet is a valuable (although more expensive) method to support fish metabolism during challenging conditions. For both diets, catabolic protein usage of rainbow trout was lowest at $16^{\circ} \mathrm{C}$ and was not altered under challenging DO conditions. For oxygen conditions above $50 \%$ saturation and all temperatures tested in this study, fish fed a dietary protein content of $42.5 \%$ demonstrated decreased protein fuel use, increased retained energy and slightly lowered $\mathrm{VO}_{2}$ compared with fish fed a higher protein diet (49.5\%). The elevated protein in the HP diet was not invested in extra growth, and the $30-40 \%$ higher rate of protein fuel use suggested that the elevated protein was catabolised completely and imposed elevated $\mathrm{VO}_{2}$ demands. Low night-time oxygen levels ( $<50 \%$ saturation) led to a decrease in the retained energy and an increase in $\mathrm{VO}_{2}$ among fish fed the SP diet, so that under these conditions the SP diet was comparable in performance with the HP diet. The decrease in retained energy under low oxygen conditions suggests that there is scope to improve the performance of SP diets under challenging conditions for rainbow trout; however, this study suggests that simply increasing the dietary protein content is not a remedy and other strategies need to be explored. 


\section{Acknowledgements}

The authors thank Stephanie Michl, Faraz Ansari, Simon Klatt, Arndt von Danwitz and Marcus Griese for assistance during the experiment or final sampling, as well as Mario Hasler for detailed statistical advices. The authors also thank Leo Nankervis and Nafiha Usman for detailed discussion of the raw data.

The present study was supported by the Ministry of Economic Affairs, Employment, Transport and Technology SchleswigHolstein (project no: 122-13-004), by the Ministry of Science, Economic Affairs and Transport Schleswig-Holstein (project no: 122-08-008) and by the Innovationsstiftung Schleswig-Holstein (ISH, later converted into the EKSH, project no: 2010-43) and Skretting ARC, Norway. This study was also supported by Systea SpA, Italy, and SubCtech GmbH, Germany. The authors thank Enrico Savino and Pompeo Moscetta from Systea and Stefan Marx and Saskia Heckmann from SubCtech.

K. T. S., K. H. V., D. M., G. R., W. K. and C. S. designed the study. K. T. S. and C. D. carried out the experiment. K. T. S. analysed the data. K. T. S., K. H. V., D. M. and C. S. wrote the manuscript.

The authors declare that there are no conflicts of interest.

\section{Supplementary material}

To view supplementary material for this article, please visit https://doi.org/10.1017/S0007114517000472

\section{References}

1. Brett JR (1979) Environmental factors and growth. In Fish Physiology Vol. 8, pp. 599-675 [WS Hoar, DJ Randall and JR Brett, editors]. New York: Academic Press.

2. Carter CG, Katersky RS, Barnes JC, et al. (2008) Assessment of fish growth performance under limiting environmental conditions: Aquaculture nutrition subprogram. FRDC Final Report, pp. 1-147. Launceston, TAS, Australia: Tasmanian Aquaculture and Fisheries Institute.

3. Colt J (2006) Water quality requirements for reuse systems. Aquacult Eng 34, 143-156.

4. Kramer DL (1987) Dissolved oxygen and fish behavior. Environ Biol Fishes 18, 81-92.

5. Wang T, Lefevre S, Thanh Huong DT, et al. (2009) Chapter 8: The effects of hypoxia on growth and digestion. In Fish Physiology, pp. 361-396 [JG Richards, AP Farrell and CJ Brauner, editors]. San Diego, CA: Academic Press.

6. Davis JC (1975) Minimal dissolved-oxygen requirements of aquatic life with emphasis on Canadian species - review. J Fish Res Board Can 32, 2295-2332.

7. Johansson D, Ruohonen K, Kiessling A, et al. (2006) Effect of environmental factors on swimming depth preferences of Atlantic salmon (Salmo salar L.) and temporal and spatial variations in oxygen levels in sea cages at a fjord site. Aquaculture 254, 594-605.

8. Remen M, Oppedal F, Imsland AK, et al. (2013) Hypoxia tolerance thresholds for post-smolt Atlantic salmon: dependency of temperature and hypoxia acclimation. Aquaculture 416, 41-47.

9. Jordan AD \& Steffensen JF (2007) Effects of ration size and hypoxia on specific dynamic action in the cod. Physiol Biochem Zool 80, 178-185.

10. Svendsen JC, Steffensen JF, Aarestrup K, et al. (2011) Excess posthypoxic oxygen consumption in rainbow trout
(Oncorbynchus mykiss): recovery in normoxia and hypoxia. Can J Zool 90, 1-11.

11. Eliason EJ \& Farrell AP (2014) Effect of hypoxia on specific dynamic action and postprandial cardiovascular physiology in rainbow trout (Oncorbynchus mykiss). Comp Biochem Physiol A Mol Integr Physiol 171, 44-50.

12. Tirsgaard B, Moran D \& Steffensen JF (2015) Prolonged SDA and reduced digestive efficiency under elevated $\mathrm{CO}_{2}$ may explain reduced growth in Atlantic cod (Gadus morhua). Aquat Toxicol 158, 171-180.

13. Taylor JC \& Miller JM (2001) Physiological performance of juvenile southern flounder, Paralichthys lethostigma (Jordan and Gilbert, 1884), in chronic and episodic hypoxia. J Exp Mar Biol Ecol 258, 195-214.

14. Farrell AP \& Richards JG (2009) Defining hypoxia: an integrative synthesis of the responses of fish to hypoxia. Fish Physiol 27, 487-503.

15. Randall DJ \& Smith JC (1967) The regulation of cardiac activity in fish in a hypoxic environment. Physiol Zool 40, 104-113.

16. Hughes GM \& Saunders RL (1970) Responses of the respiratory pumps to hypoxia in the rainbow trout (Salmo gairdneri). J Exp Biol 53, 529-545.

17. Itazawa Y (1970) Heart rate, cardiac output and circulation time of fish. Bull Jap Soc Sci Fish 36, 926-931.

18. Cameron JN (1971) Oxygen dissociation characteristics of the blood of the rainbow trout, Salmo gairdneri. Comp Biochem Physiol A Comp Physiol 38, 699-704.

19. Jones DR (1971) Theoretical analysis of factors which may limit the maximum oxygen uptake of fish: the oxygen cost of the cardiac and branchial pumps. $J$ Theor Biol 32, 341-349.

20. Kutty M (1978) Ammonia quotient in sockeye salmon (Oncorbynchus nerka). J Fish Board Can 35, 1003-1005.

21. Heldmaier G \& Neuweiler G (2004) Energiehaushalt von Tieren (Energy budget of animals). In Vergleichende Tierphysiologie, pp. 53-91. Berlin, Heidelberg: Springer.

22. Glencross BD (2009) Reduced water oxygen levels affect maximal feed intake, but not protein or energy utilization efficiency of rainbow trout (Oncorbynchus mykiss). Aquacult Nutr 15, 1-8.

23. Glencross B \& Rutherford N (2010) Dietary strategies to improve the growth and feed utilization of barramundi, Lates calcarifer under high water temperature conditions. Aquacult Nutr 16, 343-350.

24. Saravanan S (2013) Feed Intake and Oxygen Consumption in Fish. Doctoral dissertation, Wageningen University.

25. Glencross B, Blyth D, Irvin S, et al. (2014) An analysis of the effects of different dietary macronutrient energy sources on the growth and energy partitioning by juvenile barramundi, Lates calcarifer, reveal a preference for protein-derived energy. Aquacult Nutr 20, 583-594.

26. National Research Council (1993) Nutrient Requirements of Fish. Washington, DC: National Academies Press.

27. Mcleary B, Gibson T, Solah V, et al. (1994) Total starch measurement in cereal products: interlaboratory evaluation of a rapid enzymic test procedure. Cereal Chem 71, 501-505.

28. Stiller KT, Moran D, Vanselow KH, et al. (2013) A novel respirometer for online detection of metabolites in aquaculture research: evaluation and first applications. Aquacult Eng 55, 23-31.

29. Stiller KT, Moran D, Vanselow KH, et al. (2014) A novel recirculating aquaculture respirometer system (RARS) for online detection of metabolites and gassing trials under culture-like conditions. Aquacult Eng News 16, 2-3, 10.

30. Cho CY \& Kaushik SJ (1985) Effect of protein intake on metabolizable and net energy values of fish diets. In Nutrition 
and Feeding in Fish, pp. 95-117 [CB Cowey, AM Mackie and JG Bell, editors]. London: Academic Press.

31. Azevedo PA, Young Cho C, Leeson S, et al. (1998) Effects of feeding level and water temperature on growth, nutrient and energy utilization and waste outputs of rainbow trout (Oncorbynchus mykiss). Aquat Living Resour 11, 227-238.

32. Killen SS, Atkinson D \& Glazier DS (2010) The intraspecific scaling of metabolic rate with body mass in fishes depends on lifestyle and temperature. Ecol Lett 13, 184-193.

33. Stiller KT, Vanselow KH, Moran D, et al. (2015) The effect of carbon dioxide on growth and metabolism in juvenile turbot Scophthalmus maximus L. Aquaculture 444, 143-150.

34. Gnaiger E (1983) Calculation of energetic and biochemical equivalents of respiratory oxygen consumption. In Polarographic Oxygen Sensors. Aquatic and Physiological Applications, pp. 337-345 [E Gnaiger and H Forstner, editors]. Berlin: Springer.

35. Dietz C, Stiller KT, Griese M, et al. (2013) ) Influence of salinity on energy metabolism in juvenile turbot, Psetta maxima (L.). Aquacult Nutr 19, 135-150.

36. Dosdat A, Metailler R, Tetu N, et al. (1995) Nitrogenous excretion in juvenile turbot, Scophthalmus maximus (L.), under controlled conditions. Aquacult Res 26, 639-650.

37. Dosdat A, Servais F, Metailler R, et al. (1996) Comparison of nitrogenous losses in five teleost fish species. Aquaculture 141, 107-127.

38. France J \& Kebreab E (2008) Mathematical Modelling in Animal Nutrition. Wallingford: CABI International UK.

39. Elliott J \& Davison W (1975) Energy equivalents of oxygen consumption in animal energetics. Oecologia 19, 195-201.

40. R Core Team (2013) R: A Language and Environment for Statistical Computing. Vienna: R Foundation for Statistical Computing. http://www.R-project.org/

41. Thorarensen H, Kubiriza GK \& Imsland AK (2015) Experimental design and statistical analyses of fish growth studies. Aquaculture 448, 483-490.

42. Laird NM \& Ware JH (1982) Random-effects models for longitudinal data. Biometrics, 963-974.

43. Verbeke G \& Molenberghs G (2009) Linear Mixed Models for Longitudinal Data. New York: Springer Verlag, Inc.

44. Schaarschmidt F \& Vaas L (2009) Analysis of trials with complex treatment structure using multiple contrast tests. HortScience 44, 188-195.

45. Bretz F, Hothorn T \& Westfall P (2011) Multiple Comparisons Using $R$. Boca Raton, FL: CRC Press.

46. Hjeltnes B, Bxverfjord G, Erikson U, et al. (2012) Risk Assessment of Recirculating Systems in Salmonid Hatcheries. Norway: Norwegian Scientific Committee for Food Safety.

47. Good C, Davidson J, Welsh C, et al. (2010) The effects of carbon dioxide on performance and histopathology of rainbow trout Oncorbynchus mykiss in water recirculation aquaculture systems. Aquacult Eng 42, 51-56.

48. Schreckenbach K (2002) Einfluss von Umwelt und Ernährung bei der Aufzucht und beim Besatz von Fischen (Influence of environment and nutrition in rearing and stocking of fish). VDSF-Schriftenreibe Fischerei \& Naturschutz 4, 55-73.

49. Tran-Duy A, Schrama JW, van Dam AA, et al. (2008) Effects of oxygen concentration and body weight on maximum feed intake, growth and hematological parameters of Nile tilapia, Oreochromis niloticus. Aquaculture 275, 152-162.

50. Yang K, Fan Q, Zhang L, et al. (2015) Effect of dissolved oxygen levels on growth performance, energy budget and antioxidant responses of yellow catfish, Pelteobagrus fulvidraco (Richardson). Aquacult Res 46, 2025-2033.

51. Timmons M \& Ebeling J (2007) Recirculating Aquaculture. NRAC Publication no. 01-007. Ithaca, NY: Cayuga Aqua Ventures.
52. Wallace J (1993) Environmental considerations. In Salmon Aquaculture, pp. 127-143 [K Heen, R Monahan and F Utter, editors]. Oxford: Fishing News Books.

53. Matthews K \& Berg N (1997) Rainbow trout responses to water temperature and dissolved oxygen stress in two southern California stream pools. J Fish Biol 50, 50-67.

54. Cho CY (1992) Feeding systems for rainbow trout and other salmonids with reference to current estimates of energy and protein requirements. Aquaculture 100, 107-123.

55. Fry FEJ (1971) The effect of environmental factors on the physiology of fish. In Fish Physiology, Vol. 6, pp. 1-98 [WS Hoar and DJ Randall, editors]. New York: Academic Press.

56. Linton TK, Morgan I, Walsh P, et al. (1998) Chronic exposure of rainbow trout (Oncorbynchus mykiss) to simulated climate warming and sublethal ammonia: a year-long study of their appetite, growth, and metabolism. Can J Fish Aquat Sci 55 , 576-586.

57. Morgan IJ, McDonald DG \& Wood CM (2001) The cost of living for freshwater fish in a warmer, more polluted world. Global Change Biol 7, 345-355.

58. Alsop DH \& Wood CM (1997) The interactive effects of feeding and exercise on oxygen consumption, swimming performance and protein usage in juvenile rainbow trout (Oncorbynchus mykiss). J Exp Biol 200, 2337-2346.

59. Wilson RP (2002) Amino acids and proteins. In Fish Nutrition, 3rd ed., pp. 143-179 [JE Halver and RW Hardy, editors]. San Diego, CA: Academic Press.

60. Glazier DS (2015) Is metabolic rate a universal 'pacemaker' for biological processes? Biol Rev $90,377-407$.

61. Dumas A, France J \& Bureau D (2010) Modelling growth and body composition in fish nutrition: where have we been and where are we going? Aquacult Res 41, 161-181.

62. Herrmann RB, Warren CE \& Doudoroff P (1962) Influence of Oxygen Concentration on the Growth of Juvenile Coho Salmon. Trans Am Fish Soc 91, 155-167.

63. Chabot D \& Claireaux G (2008) Environmental hypoxia as a metabolic constraint on fish: the case of Atlantic cod, Gadus morhua. Mar Poll Bull 57, 287-294.

64. Kutty MN (1968) Influence of ambient oxygen on the swimming performance of goldfish and rainbow trout. Can J Zool 46, 647-653.

65. Dalsgaard J, Larsen BK \& Pedersen PB (2015) Nitrogen waste from rainbow trout (Oncorbynchus mykiss) with particular focus on urea. Aquacult Eng 65, 2-9.

66. Kajimura M, Croke SJ, Glover CN, et al. (2004) Dogmas and controversies in the handling of nitrogenous wastes: the effect of feeding and fasting on the excretion of ammonia, urea and other nitrogenous waste products in rainbow trout. $J$ Exp Biol 207, 1993-2002.

67. Lauff RF \& Wood CM (1996) Respiratory gas exchange, nitrogenous waste excretion, and fuel usage during aerobic swimming in juvenile rainbow trout. J Comp Physiol B 166, 501-509

68. Lauff RF \& Wood CM (1996) Respiratory gas exchange, nitrogenous waste excretion, and fuel usage during starvation in juvenile rainbow trout, Oncorbynchus mykiss. I Comp Physiol B 165, 542-551.

69. Lauff RF \& Wood CM (1997) Effects of training on respiratory gas exchange, nitrogenous waste excretion, and fuel usage during aerobic swimming in juvenile rainbow trout (Oncorhynchus mykiss). Can J Fish Aquat Sci 54, 566-571.

70. Wood CM (2001) Influence of feeding, exercise, and temperature on nitrogen metabolism and excretion. In Nitrogen Excretion, pp. 201-238 [E Wright, P Wright and P Anderson, editors]. San Diego, CA: Academic Press. 